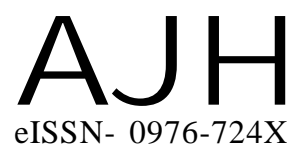

Article history :

Received : 07.05.2014

Revised : 02.11.2014

Accepted : 16.11.2014
Members of the Research Forum

Associated Authors:

${ }^{1}$ Department of Horticulture, Udai Pratap Autonomous College,

VARANASI (U.P.) INDIA

${ }^{2}$ Department of Horticulture, N.D. University of Agriculture and Technology, Kumarganj, FAIZABAD (U.P.) INDIA
Author for correspondence J.K. SINGH

Department of Horticulture, N.D. University of Agriculture and

Technology, Kumarganj, FAIZABAD (U.P.) INDIA

Email : jitendra_hort@yahoo.com
THE ASIAN JOURNAL OF HORTICULTURE

Volume 9 | Issue 2 | Dec., 2014|421-425

Visit us -www.researchjournal.co.in

\title{
Studies on integrated nutrient management of vegetative growth, fruiting behaviour and nutrient status of leaves and soil of bael (Aegle marmelos Correa) orchard cv. NARENDRA BAEL-9
}

\section{J.K. SINGH, D.K. SINGH ${ }^{1}$ AND H.K. SINGH ${ }^{2}$}

ABSTRACT : The experiment was carried out at Main Experiment Station Horticulture, Narendra Deva University of Agriculture and Tech., Kumarganj, Faizabad (U.P.) during the year 2007-08 and 2008-09, to evaluate the response of organic manures, inorganic fertilizers, biofertilizers and their combination with foliar spray of 0.4 per cent boron on vegetative growth, fruiting behavior and nutrient status of leaves and soil of bael orchard cv. NARENDRA BAEL-9. The vegetative growth of plant viz., plant height, spread and trunk girth were recorded maximum with the application of $\mathrm{T}_{10}(100 \% \mathrm{NPKB}$ + biofertilizers + biopressmud + FYM $)$ closely followed by $\mathrm{T}_{14}(50 \% \mathrm{NPKB}+$ biofertilizers + biopressmud + FYM). However, the maximum fruit set, fruit retention and minimum fruit drop were recorded with the application of $\mathrm{T}_{10}(100 \% \mathrm{NPKB}+$ biofertilizers + biopressmud + FYM $)$ which was at par with $\mathrm{T}_{14}(50 \% \mathrm{NPKB}+$ biofertilizers + biopressmud + FYM $)$ during both the years of experimentation. The maximum reduction in soil $\mathrm{pH}, \mathrm{EC}$ and maximum nutrient status of leaves $(\mathrm{N}$, $\mathrm{P}, \mathrm{K})$ and soil $(\mathrm{N}, \mathrm{P}, \mathrm{K}, \mathrm{Ca}, \mathrm{Mg}$ and $\mathrm{OC})$ were obtained with $\mathrm{T}_{10}(100 \% \mathrm{NPKB}+$ biofertilizers + biopressmud + FYM) closely followed by $\mathrm{T}_{14}(50 \% \mathrm{NPKB}+$ biofertilizers + biopressmud + FYM $)$. All the treatments were effective to improve the vegetative growth, fruiting behaviour and nutrient status of leaves and soil of bael orchard as compared with control. However, $\mathrm{T}_{14}(50 \% \mathrm{NPKB}+$ biofertilizers + biopressmud + FYM) was found to be best on overall basis and economic feasibility of treatment.

KEY WORDS : Biofertilizers, Biopressmud, FYM, NPK, Growth, Fruiting, Nutrient status, Bael

HOW TO CITE THIS ARTICLE : Singh, J.K., Singh, D.K. and Singh, H.K. (2014). Studies on integrated nutrient management of vegetative growth, fruiting behaviour and nutrient status of leaves and soil of bael (Aegle marmelos Correa) orchard cv. NARENDRA BAEL-9. Asian J. Hort., 9(2) : 421-425. 